\title{
The Jak-Stat pathway in normal and perturbed hematopoiesis
}

\author{
Alister C. Ward, Ivo Touw, and Akihiko Yoshimura
}

The Janus kinase-signal transducer and activator of transcription (Jak-Stat) pathway stands as a paradigm of how diverse extracellular signals can elicit rapid changes in gene expression in specific target cells. This pathway is widely used by members of the cytokine receptor superfamily, including those for the clinically important cytokines granulocyte colony-stimulating factor (GCSF), erythropoietin, thrombopoietin, the interferons, and numerous interleukins, which makes it central to hematopoietic cell biology and hematologic therapy alike. Indeed, study of the Jak-Stat pathway has provided a wealth of information on hematopoiesis and hematopoietic disease, and conversely, studies of hematopoietic disorders have yielded new insights into the functions of Jaks and Stats. This review aims to detail the role of the Jak-Stat pathway in the normal development and function of hematopoietic cells and to describe how several hematopoietic disorders are caused, at least in part, by perturbations of this pathway.

\section{Jaks}

Jaks are cytoplasmic tyrosine kinases that participate in signaling from a range of cell-surface receptors, particularly members of the cytokine receptor superfamily, which lack intrinsic tyrosine kinase activity. ${ }^{1,2}$ There are 4 mammalian Jaks: Jak1, Jak2, Jak3, and Tyk2. These associate with the weakly conserved "box 1" and "box 2" recognition motifs in the membrane-proximal region of cytokine receptors ${ }^{3,4}$ and are responsible for a range of phosphorylation events on stimulation of such receptors with their specific ligand. In addition, some receptors that have tyrosine kinase activity, such as those for macrophage colony-stimulating factor and stem cell factor, also activate Jaks, though it is unclear what role they play in these instances.., 6

Cell lines deficient for either Jak1 or Jak2 are unable to mediate a response to interferon- $\gamma$, whereas those deficient in Tyk 2 fail to respond to interferon- $\alpha / \beta .^{7-9}$ In addition, the expression of kinasedeficient Jaks or the introduction of mutations that prevent Jak binding and activation abolishes the proliferative and antiapoptotic signaling from a number of other cytokine receptors. ${ }^{10-14}$ The essential role of Jaks in mediating the effects of these hematopoietic regulators was recently confirmed by targeted disruption of the corresponding murine genes (Table 1). Jakldeficient mice exhibited perinatal lethality, apparently because of defective neural function, and defective lymphoid development. ${ }^{15}$ Targeted disruption of the Jak2 gene resulted in an embryonic lethal phenotype caused by a block in definitive erythropoiesis but with intact lymphoid development. ${ }^{16,17}$ In both cases, a number of other specific cytokine-induced biologic responses were absent or impaired. Finally, Jak3 knockout mice exhibited severe combined immunodeficiency, with markedly reduced numbers of functional $\mathrm{T}$ and B lymphocytes, ${ }^{18,19}$ and dysregulated myelopoiesis. ${ }^{20}$ Thus, the Jaks collectively are vital for normal hematopoietic function, which can be explained by their nonredundant role in the signaling of specific cytokines (Table 1).

\section{Stats}

Stats are latent cytoplasmic transcription factors that become activated after recruitment to an activated receptor complex. Subsequently, these active Stats translocate to the nucleus to affect gene expression. Seven Stat proteins have been identified in mammalian cells-Stats1 to 6, including Stat5a and Stat5b, which are encoded by distinct genes. In addition, different isoforms of several Stats have been identified. ${ }^{21}$

Targeted inactivation of Stat genes in the mouse also resulted in severe effects on the development and function of hematopoietic cells (Table 2). Stat1 knockout mice showed defective innate immune responses to viruses and bacteria because of the absence of interferon signaling, ${ }^{22,23}$ whereas Stat 2 knockout mice showed defective responses to interferon $\alpha / \beta$ (C. Schindler, personal communication, 1999). Targeted disruption of the Stat3 gene produced early embryonic lethality. ${ }^{24}$ Subsequently, T-cell-specific Stat3-deficient mice were generated that were severely impaired in IL-6-induced proliferation because of enhanced apoptosis. ${ }^{25}$ Stat4 knockout mice were defective in the formation of Th1 cells, largely a result of disrupted IL-12 receptor function. ${ }^{26,27}$ Mice with both Stat5a and Stat5b genes disrupted showed multiple defects, with responses to IL-2, IL-3, granulocyte-macrophage colony-stimulating factor (GM-CSF), and granulocyte colony-stimulating factor (G-CSF) affected, ${ }^{28,29}$ whereas the respective single Stat5 knockouts also exhibited defective proliferative responses to specific cytokines. ${ }^{30,31}$ Finally, a block in Th2 cell development and IgE class switching was observed in Stat6 knockout mice. ${ }^{32,33}$

Further evidence of the vital role of Stats in cytokine receptor signaling has been obtained from studies in cell lines. For example, a mutant cell line deficient in Stat1 expression showed a block in interferon signaling similar to that in Stat1 knockout mice. ${ }^{34}$ Other studies using dominant-negative Stats or specific receptor mutants have shown, for example, that Stat 3 activation plays a key role in the differentiation responses to IL-6 and G-CSF, ${ }^{35-37}$ whereas Stat5
From the Institute of Hematology, Erasmus University, Rotterdam, The Netherlands; and the Institute of Life Science, Kurume University, Japan.

Submitted May 3 1999; accepted August 6, 1999.

Supported by an EMBO Long Term Fellowship and the NWO (A.C.W.) and by grants from the Ministry of Science, Education and Culture of Japan, the TORAY Research Foundation, and the Uehara Memorial Research Foundation (A.Y.).
Reprints: Alister C. Ward, Institute of Hematology, Erasmus University Rotterdam, P. O. Box 1738, 3000 DR Rotterdam, Netherlands; e-mail: ward@hema.fgg.eur.nl.

The publication costs of this article were defrayed in part by page charge payment. Therefore, and solely to indicate this fact, this article is hereby marked "advertisement" in accordance with 18 U.S.C. section 1734.

(C) 2000 by The American Society of Hematology 
Table 1. Jaks in hematopoiesis: phenotype of mouse knockouts

\begin{tabular}{|c|c|c|c|}
\hline $\begin{array}{l}\text { Jak } \\
\text { Type }\end{array}$ & Relevant Phenotypes & Cytokines Affected & Refs \\
\hline Jak1 & $\begin{array}{l}\text { - Impaired lymphoid develop- } \\
\text { ment } \\
\text { Defective responses to class } 2 \\
\text { cytokines and those using } \gamma c \\
\text { or gp130 receptor subunits }\end{array}$ & $\begin{array}{l}\text { IL-2, IL-4, IL-6, IL-7, IL-9, IL-10, } \\
\text { IL-15, LIF, all interferons }\end{array}$ & 15 \\
\hline Jak2 & - No definitive erythropoiesis & $\begin{array}{l}\text { EPO, TPO, IL-3, IL-5, GM-CSF, } \\
\text { IFN- } \gamma\end{array}$ & 16,17 \\
\hline Jak3 & $\begin{array}{l}\text { Defective lymphoid develop- } \\
\text { ment } \\
\text { - Dysregulated myelopoiesis }\end{array}$ & IL-4, IL-7, IL-9, IL-15 & $18-20$ \\
\hline
\end{tabular}

EPO, erythropoietin; IFN, interferon; IL, interleukin; TPO, thrombopoietin.

appears very important for proliferative responses to IL-3, IL-5, G-CSF, and GM-CSF ${ }^{38-40}$ and for neutrophilic differentiation in response to G-CSF. ${ }^{40}$ Interestingly, these latter studies differ from the relative mild effects on hematopoiesis seen in Stat5ab double knockout mice, ${ }^{28}$ and they serve to highlight some of the potential problems in interpreting both model systems. For example, compensatory overlapping pathways can mask the physiological consequences of a gene disruption in a whole animal, whereas effects seen in cell lines may represent physiologically irrelevant endpoints or nonspecific consequences of a presumed dominant-negative protein acting on other pathways. However, both types of studies have together yielded great insight into the biologic function of Stats.

\section{Jak-Stat pathway}

A general model of Jak-Stat activation from cytokine receptors has been proposed, ${ }^{2,21,41}$ though there are several exceptions and

Table 2. Stats in hematopoiesis: phenotypes of mouse knockouts

\begin{tabular}{|c|c|c|c|}
\hline Stat Type & Relevant Phenotypes & Cytokines Affected & Refs \\
\hline Stat1 & $\begin{array}{l}\text { - Interferon responses absent: } \\
\text { —innate immune responses } \\
\text { absent } \\
\text { —-highly sensitive to viral/microbial } \\
\text { infection } \\
\text { _IFN-responsive genes not acti- } \\
\text { vated }\end{array}$ & IFNs only & 22,23 \\
\hline Stat 2 & $\begin{array}{l}\text { - Type } 1 \text { interferon responses } \\
\text { impaired }\end{array}$ & IFN- $\alpha / \beta$ & $\begin{array}{l}\text { C. Schindler, } \\
\text { pers. comm. }\end{array}$ \\
\hline Stat 3 & - Embryonic lethal & & 24 \\
\hline Stat 4 & $\begin{array}{l}\text { - IL-12 responses absent } \\
\downarrow \text { production of high IFN- } \gamma \text {, low } \\
\text { IFN- } \gamma \text { R } \alpha \text { Th1 cells } \\
\downarrow \text { priming for high level IFN- } \gamma \text { pro- } \\
\text { duction } \\
\downarrow \text { lymphocyte proliferation } \\
\downarrow \text { enhancement of NK cell-medi- } \\
\text { ated cytotoxicity } \\
\uparrow \text { Th2 cells }\end{array}$ & IL-12 only & 26,27 \\
\hline Stat5ab & $\begin{array}{l}\text { - Proliferation signaling affected: } \\
\downarrow \text { CFU-Mix, Eos, G, GM, Pre-B } \\
\downarrow \text { peripheral T cells } \\
\text { Absence of NK cells }\end{array}$ & $\begin{array}{l}\text { IL-2, IL-3, } \\
\text { IL-7, GM-CSF, } \\
\text { G-CSF }\end{array}$ & 28,29 \\
\hline Stat6 & $\begin{array}{l}\text { - IL-4 responses absent: } \\
\text {-Absence of IL-4 producing Th2 } \\
\text { cells } \\
\text {-Block in B-cell IgE class switching } \\
\downarrow \text { lymphocyte proliferation (partial) } \\
\downarrow \text { expression of IL-4-induced cell } \\
\quad \text { surface markers }\end{array}$ & IL-4 only & $32,33,179$ \\
\hline
\end{tabular}

CFU, colony-forming unit: G-CSF, granulocyte colony-stimulating factor; GMCSF, granulocyte-macrophage colony-stimulating factor; IFN, interferon; IL, interleukin; NK, natural killer. variations on the basic theme first elucidated for the interferon receptors. ${ }^{42}$ Binding of ligand to a cytokine receptor leads to the activation of Jaks, presumably through autophosphorylation on tyrosines (Figure 1). Activated Jaks then phosphorylate the receptor, creating docking sites for specific signaling proteins, including Stat proteins, which the Jaks can then phosphorylate on a conserved tyrosine residue at their C-terminus. Subsequently, the Stats form stable homodimers and heterodimers by interactions between the Src homology 2 (SH2) domain of one Stat protein and the phosphotyrosine of another before translocation to the nucleus, where they influence transcription of target genes by binding to specific regulatory sequences..$^{21,41}$

\section{Specificity in the Jak-Stat pathway}

Specificity in cytokine signaling is largely determined by the combination of activated Jaks and Stats. A wide range of cytokines and growth factors activate Jak1, Jak2, and Tyk, whereas Jak3 is only activated by cytokines that have the common $\gamma$-chain as a component of their receptor complex. ${ }^{43}$ Receptors show more specificity in their ability to recruit and activate Stats. For example, stimulation with interferon (IFN)- $\alpha$ or IFN- $\beta$ leads to phosphorylation of Stats 1 and 2, which form a complex with a third protein, p48. ${ }^{44}$ In contrast, G-CSF stimulation leads to the activation of Stat 3 and Stat 5 homodimers, some Stat 1 homodimers, and Stat1/3 and Stat $3 / 5$ heterodimers. ${ }^{45,46}$ Such studies have led to the suggestion that diversity within the type of Stat complexes activated contributes to the nature of the cellular responses to a given cytokine or growth factor. ${ }^{47}$ The subsequent gene knockout and dominant-negative mutant studies described above have largely supported this hypothesis.

The specificity of Stat activation is partially mediated through their recruitment to specific cytoplasmic tyrosines of particular receptors through their SH2 domains. For example, tyrosine 440 in the cytoplasmic domain of the IFN- $\gamma$ receptor $\alpha$ chain is responsible for recruitment and activation of Stat $1,{ }^{48}$ whereas tyrosines 578 and 606 of the IL-4-R are required for phosphorylation and activation of Stat6. ${ }^{49}$ Similarly, numerous studies have identified the YxxQ motif as a consensus Stat3 docking site, though it can bind to other motifs. ${ }^{45,50,51}$ In addition, several examples of Stat activation that do not require direct docking to receptor tyrosines have been reported. For instance, full activation of Stat1 by G-CSF or growth hormone and of Stat5 by G-CSF and GM-CSF occurs in the complete absence of receptor tyrosines. ${ }^{38,45,51,52}$ It has been proposed that Jak1 and Jak 2 can specifically recruit and phosphorylate Stat1 and Stat5, respectively, ${ }^{53,54}$ which could explain their activation in these cases. However, there is growing evidence that other receptor components can also act as docking sites for Stats. ${ }^{45,55}$ For example, Stat 1 is recruited to the IFN- $\alpha / \beta$ receptor complex by binding to a Stat 2 molecule already docked to the activated receptor. ${ }^{21}$ Thus, Stat specificity is determined by recruitment to the receptor complex in toto rather than simply to the linear sequence of each receptor. However, the particular Jaks and Stats activated may also be dependent on the cell-type or its state of differentiation, ${ }^{21,56-58}$ and receptor "cross-talk" may further modify the response elicited. For example, IL-4 inhibits IL-2mediated Stat5 activation, ${ }^{59}$ IL-10 suppresses interferon-mediated Stat activation, ${ }^{60}$ and cyclic adenosine monophosphate impairs IL-2-dependent signaling by downregulating levels of the Jak3 protein itself. $^{61}$

Individual Stats bind to similar DNA response elements, mostly 
Figure 1. Activation of the Jak-Stat pathway by cytokine receptors and its regulation by CIS family members and tyrosine phosphatases.

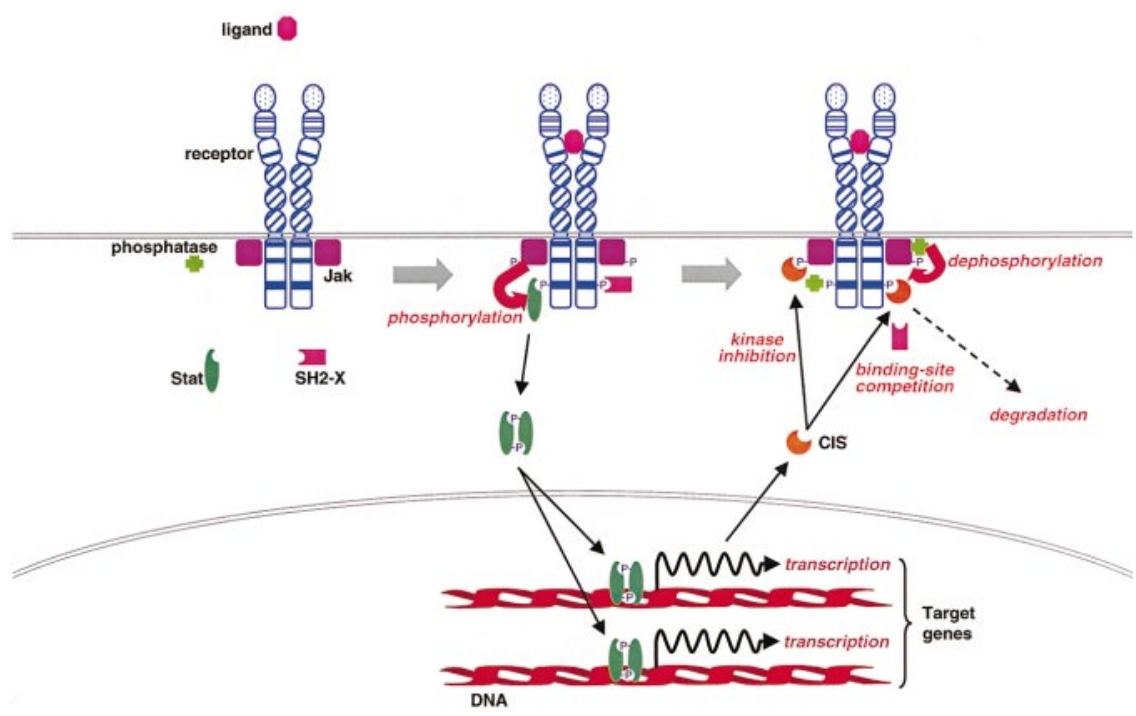

related to a $\gamma$ interferon-activated site, a regulatory element in the promoter of IFN- $\gamma$-inducible genes. ${ }^{42}$ However, the recognition sites are not identical, ${ }^{62-64}$ and so different genes are targeted for induction by different Stats (Table 3). In addition, Stats can mediate transcriptional repression at specific promoters. ${ }^{65,66}$ Some Stats are able to form both homodimers and heterodimers, which can further broaden the range of Stat/DNA-binding specificities. ${ }^{21}$ The duration of Stat activation is also able to influence the transcriptional program induced. ${ }^{21,46}$ In addition, various Stat isoforms are differentially expressed in specific cell types, which can also have an impact on the expression of Stat-responsive genes. ${ }^{21,57,58,65}$ It has recently been shown that Stats can interact with a range of other nuclear factors and coactivators, including CBP, Nmi, the glucocorticoid receptor c-Jun, and MCM5, ${ }^{21,67-69}$ which increases the range of transcriptional responses in which Stats can participate. Finally, though phosphorylation of the C-terminal tyrosine is critical for Stat activation, serine phosphorylation probably also modulates the transcriptional response. ${ }^{70-73}$ Indeed, it was shown that Ser727 of Stat $1 \alpha$ is directly involved in the recruitment of MCM5 as part of IFN- $\gamma$-induced transcriptional activation. ${ }^{68}$ Together, this complex control of specificity enables an individual hematopoietic cell to elicit the appropriate transcriptional response to incoming signals from cytokines, growth factors, and other stimuli.

\section{Independent functions of Jaks and Stats}

The major function of Jaks is generally considered to be Stat activation. However, this is clearly not the only role that Jaks play in signaling. For example, Jaks are directly implicated in the activation of the kinase Pyk2, ${ }^{74}$ stimulation of the Ras-MAPK pathway, ${ }^{13,75,76}$ and the induction of the c-fos and c-myc genes. ${ }^{77}$ Conversely, there is considerable evidence that some activation of Stats occurs independently of Jaks. For example, cell lines deficient in Jak2 or Tyk2 showed no effect on G-CSF-dependent Stat activation, and a cell line deficient in Jak1 showed only partial reduction in Stat 3 activation. ${ }^{55}$ Similar results were obtained with Jak knockout mice for a range of factors. ${ }^{16}$ Furthermore, Stat6 activation after CD40 engagement occurs independently of detectable Jak phosphorylation. ${ }^{78}$ Such data suggest that other kinases are probably also involved in mediating Stat activation. In support of this, Src has been shown to bind and activate Stat 3 directly, ${ }^{79}$ whereas Bcr-Abl can also recruit and activate Stat5 by the interaction of Stat5 with the adaptor CrkL, which itself docks to Bcr-Abl. ${ }^{80}$ Other work implicates a number of non-Jak kinases as responsible for the serine phosphorylation of Stats. ${ }^{73,81}$

\section{Negative regulation of the Jak-Stat pathway}

As further evidence of the importance of the Jak-Stat pathway, negative feedback mechanisms have been identified that control its activation (Table 4). These include endosomal degradation of Jak/receptor complexes through receptor-mediated endocytosis ${ }^{82,83}$ and the dominant-negative effects of several naturally occurring Stat variants. ${ }^{84,85}$ In addition, the PIAS proteins have been identified. They seem to bind directly to Stats and to inhibit DNA binding, though their exact biologic role remains unclear. ${ }^{72,86}$ Two other means of negative regulation, by CIS/SOCS/SSI family members and by tyrosine phosphatases, have been studied in more detail.

\section{CIS/SOCS/SSI Family}

This family, variously called CIS, SOCS, or SSI, is a group of small proteins containing $\mathrm{SH} 2$ and CIS homology $(\mathrm{CH})$ domains (also called SOCS boxes). At least 8 family members have been identified (CIS1 to CIS7 and JAB), ${ }^{87,88}$ which are involved in the relatively specific regulation of cytokine signaling. ${ }^{89}$

The first member of this family, originally denoted CIS (now

Table 3. Genes induced by Stat proteins

\begin{tabular}{|c|c|c|}
\hline Stat & Genes Encoding & Refs \\
\hline Stat1 & $\begin{array}{l}\text { ISG54, IRF-1, CIITA, mig, 2,3 dioxygenase, } \\
\text { GBP, p21 }\end{array}$ & $22,23,64$ \\
\hline Stat3 & $\begin{array}{l}\text { JunB, SAA3, JAB, C-reactive protein, Bclx } x_{L} \text {, } \\
\text { p21 }\end{array}$ & $63,64,98,134,136$ \\
\hline Stat4 & IFN- $\gamma$, IRF-1, Fc- $\gamma \mathrm{RI}, \mathrm{CD} 23, \mathrm{MHC}$ class II & 33,180 \\
\hline Stat5 & $\begin{array}{l}\beta \text {-casein, IL-2R- } \alpha, \text { CIS, osm, pim1, p21, } \\
\text { cyclin D1 }\end{array}$ & $92,181-183$ \\
\hline Stat6 & IL-4R- $\alpha$, Fc- $\epsilon$ RIIa, C- $\epsilon$, C- $\gamma 1$, C- $\gamma 4$ & $21,63,64$ \\
\hline Stat $1 /$ Stat $1 / p 48$ & GBP & 64 \\
\hline $\begin{array}{l}\text { Stat1/Stat2/p48 } \\
\quad \text { (ISGF3) }\end{array}$ & $\begin{array}{l}\text { ISG15, ISG54, 6-16, 2',5' oligoadenylate } \\
\text { synthetase, 2,3-dioxygenase }\end{array}$ & 64 \\
\hline
\end{tabular}

IFN, interferon; IL, interleukin; MHC, major histocompatibility complex. 
Table 4. Negative regulatory mechanisms of the Jak-Stat pathway

\begin{tabular}{lc}
\hline \multicolumn{1}{c}{ Mechanism } & Refs \\
\hline Receptor-mediated endocytosis & 82,83 \\
Dominant-negative Stats & 84,85 \\
PIAS family of proteins & 72,86 \\
CIS/SOCS/SSI family of proteins & 88,89 \\
Tyrosine phosphatases & 114,115 \\
\hline
\end{tabular}

called CIS1) for cytokine-induced SH2-containing protein, was cloned as an immediate early gene that was induced by IL-2, IL-3, and erythropoietin. ${ }^{90,91}$ The induced CIS protein can subsequently associate with specific tyrosines of the activated receptors, ${ }^{92}$ including one of the major Stat 5 binding sites of the erythropoietin receptor. ${ }^{93}$ Forced expression of CIS1 partially suppresses IL-3 or erythropoietin-induced proliferation and Stat5 activation..$^{92}$ Conversely, Stat5 activates the CIS1 promoter through interaction with tandem TTCNNNGAA motifs, ${ }^{92}$ with CIS1 expression absent in the ovaries of Stat $5 a b$ double knockout mice. ${ }^{28}$ Thus, CIS1 appears to act as a negative feedback regulator of the Jak-Stat5 pathway. This is supported by recent observations in CIS1-transgenic mice that exhibited a phenotype similar to that observed in Stat5ab double knockout mice. ${ }^{94}$

The second CIS/SOCS/SSI family member, JAB (also called SOCS-1, SSI-1, and TIP-3), was identified independently because of its ability to interact with the kinase domains of Jak2 and Tec, ${ }^{95,96}$ to inhibit the IL-6-induced differentiation and growth arrest of a leukemic cell line, ${ }^{97}$ and to be recognized by an antibody to Stat $\mathrm{SH} 2$ domains. ${ }^{98}$ Overexpression of JAB can inhibit virtually any signal using Jaks, such as Stat5 activation by erythropoietin, Stat3 activation by leukemia inhibitory factor or IL-6, and c-fos induction by IL-2. However, JAB does not inhibit fibroblast growth factor (FGF)-induced c-fos activation or c-Kit phosphorylation, though it binds to the FGF receptor and c-Kit. ${ }^{87}$ Although JAB was found to suppress Tec kinase activity, this effect was marginal compared with its effect on Jaks. Therefore, JAB-mediated kinase inhibition seems to be specific for Jak tyrosine kinases; binding does not always imply inhibition. However, recently JAB has been shown to bind inducibly to the c-Kit receptor tyrosine kinase through its $\mathrm{SH} 2$ domain. ${ }^{95,99}$ Although JAB did not inhibit the catalytic activity of the c-Kit tyrosine kinase, it inhibited c-Kitmediated proliferation signals, probably by interaction with the SH3 domains of the signaling proteins Grb2 and Vav, thereby suppressing their function. ${ }^{99}$ In certain circumstances JAB may also be able to suppress signals from non-Jak tyrosine kinases. JAB knockout mice displayed growth retardation, fatty degeneration of the liver, and monocytic infiltration of several organs. They died before weaning within 3 weeks of birth. ${ }^{100,101}$ Lymphocytes in the thymus and spleen of these mice exhibited accelerated apoptosis, and at 10 days of age their numbers were $20 \%$ to $25 \%$ of those in wild-type mice. ${ }^{100}$ Among various pro-apoptotic and anti-apoptotic molecules examined, an upregulation of Bax was found in lymphocytes of the spleen and thymus of knockout mice. ${ }^{100}$ In addition, there was a progressive loss of maturing B lymphocytes in the bone marrow, spleen, and peripheral blood, whereas constitutive activation of Stat1 was found in the liver of JAB knockout mice. ${ }^{101}$ Part of this phenotype clearly resembles that found in IFN- $\gamma$-transgenic mice. ${ }^{102}$ In addition, hematopoietic progenitor cells from JAB knockout mice were hyperresponsive to IFN- $\gamma$, with the degree of inhibition varying markedly with the stimulating factor used. ${ }^{103}$ It is important to note that many of the pathologic conditions observed in JAB knockout mice can be eliminated by antibody injections or by crossing them with IFN- $\gamma$ knockout mice. ${ }^{104}$
Therefore, JAB appears to act as a negative regulator of IFN- $\gamma /$ Stat 1 and probably functions by preventing apoptosis induced by Stat1. However, other studies suggest that JAB may also inhibit other pathways that induce Bax expression, thereby preventing Bax-induced apoptosis in vivo. ${ }^{100}$

So how do the CIS family members exert their negative effects on Jak-Stat signaling? Several possibilities, which are not mutually exclusive, are shown in Figure 1. Among CIS family members, $\mathrm{JAB}$ and CIS3 are able to bind the Jak2 catalytic (JH1) domain, ${ }^{87}$ leading to direct inhibition of the Jak kinase. ${ }^{105}$ Binding requires the SH2 domain plus an additional N-terminal 12 amino acids (extended SH2 subdomain) containing 2 residues (Ile68 and Leu75) that are conserved in the CIS family. ${ }^{14,105}$ This subdomain interacts with the tyrosine residue Y1007 in the activation loop of Jak2, whose phosphorylation is critical for the induction of kinase activity. ${ }^{106,107}$ Other CIS family members bind directly to receptors, where they may function by preventing stimulatory signaling pathways coupled to specific phosphotyrosine motifs on receptors. ${ }^{92,93}$ Alternatively, given that CIS proteins have a relatively short half-life, they may act as scavengers of activated receptor complexes, targeting them for degradation..$^{93}$ In support of this, it has been shown that CIS1 itself is ubiquitinylated, ${ }^{93}$ whereas the $\mathrm{CH}$ domain appears to interact with components of the proteasomal degradation pathway. ${ }^{108-110}$ However, other studies have shown that the $\mathrm{CH}$ domain of $\mathrm{JAB}$ may actually protect this molecule from degradation. ${ }^{108,111}$ Clearly more work is required to unravel the various intracellular functions of the CIS family members.

\section{Tyrosine phosphatases}

Several studies have shown that an important negative regulatory mechanism of the Jak-Stat pathway involves the recruitment of tyrosine phosphatases containing tandem SH2 domains (SHP-1 and SHP-2) to receptor complexes. Both phosphatases can bind either activated receptors or to Jak family members themselves, leading to dephosphorylation of the kinase (Figure 1). ${ }^{112-115}$ This, in turn, leads to reduced activation of Jak-Stat pathway components. ${ }^{114,116}$ The potential in vivo importance of this mechanism is strongly suggested by the phenotype of motheaten (me/me) mice lacking SHP-1, which die of a disease with components of autoimmunity and inflammation. ${ }^{117}$ However, it remains to be elucidated whether enhanced Jak kinase activity is entirely responsible for the motheaten phenotype because SHP-1 has also been shown to regulate negatively a number of receptor and nonreceptor tyrosine kinases. ${ }^{118,119}$ In addition, though it is clear that the major means by which Stat activity is attenuated is through dephosphorylation by protein tyrosine phosphatases, ${ }^{21}$ it is unknown whether SHP-1 or SHP-2 or some other phosphatase is responsible. However, it appears that SHP-1 can associate directly with Stat5, implicating it in the direct dephosphorylation and deactivation of this Stat. ${ }^{120}$

\section{Jaks, Stats, and hematopoietic diseases}

The wide use of the Jak-Stat pathway by hematologically important factors, the severity of artificially disrupting the Jak-Stat pathway on hematopoiesis, and the number of key genes with Stat-response elements already provides some appreciation of the importance of this pathway in hematopoiesis and the regulation of hematopoietic cell function. We will now summarize the studies showing that several diverse hematopoietic disorders exhibit perturbations in the Jak-Stat pathway. Indeed, in a number of these cases, experiments have directly implicated the altered Jak or Stat signaling, or both, in 
the pathogenesis of the disease. Such molecular investigations provide a foundation on which to build an understanding of these conditions and a framework for rational improvements in therapy.

\section{Hematopoietic malignancies}

\section{Aberrant activation of Jaks and Stats}

The most direct evidence implicating dysregulation of the Jak-Stat pathway in hematopoietic malignancies was the identification of Tel-Jak2 fusions in lymphoid and myeloid leukemias. ${ }^{121,122}$ In early B-precursor acute lymphoblastic leukemia, $\mathrm{t}(9 ; 12)(\mathrm{p} 24 ; \mathrm{p} 13)$ translocations were responsible, whereas in the case of atypical chronic myeloid leukemia there was a complex $\mathrm{t}(9 ; 15 ; 12)(\mathrm{p} 24 ; \mathrm{q} 15 ; \mathrm{p} 13)$ translocation. In each case, the helix-loop-helix oligomerization domain of the transcription factor Tel is fused to the catalytic JH1 domain of Jak2 (Figure 2), which leads to constitutive association and hence activation of the kinase and constitutive activation of Stat proteins. ${ }^{123,124}$ However, Jaks and Stats are also known to be constitutively activated in hematopoietic cells transformed by diverse oncogenic tyrosine kinases (Table 5), as well as in a variety of lymphomas and leukemias, including those transformed by oncogenic viruses (Table 6). For the oncogenic tyrosine kinases, the activation of Stats may be direct or occur through Jaks, whereas the oncogenic viruses activate a number of cytoplasmic kinases to mediate the constitutive Stat activation observed (Figure 3). ${ }^{125}$

\section{Evidence for Jak-Stat involvement}

Although the data above are suggestive of a positive role for constitutive activation of the Jak-Stat pathway in leukemia, the results are largely correlative. However, other studies have provided more direct evidence for this hypothesis. For example, overexpression of a Tel-Jak2 fusion is sufficient to render $\mathrm{Ba} / \mathrm{F} 3$ cells factor-independent, ${ }^{121,123}$ and mice transplanted with retrovirus expressing this fusion develop a fatal mixed myeloproliferative and T-cell lymphoproliferative disorder with a latency of 2 to 10 weeks. ${ }^{123}$ In addition, 2 mutants of the Drosophila Jak kinase have been identified that lead to leukemia-like defects through hyperactivation of the kinase. ${ }^{126,127}$ Murine homologues of this Jak mutant have been further shown to induce leukemia in mice. ${ }^{127}$ Finally, inhibition of constitutive Jak2 phosphorylation in primary pre-B leukemic cells with the Jak2 inhibitor AG490 is able to inhibit cell proliferation. ${ }^{128}$ However, other studies suggest that the constitutive Jak activation seen in transformed cells is not actually required for transformation. Thus, dominant-negative Jaks are unable to

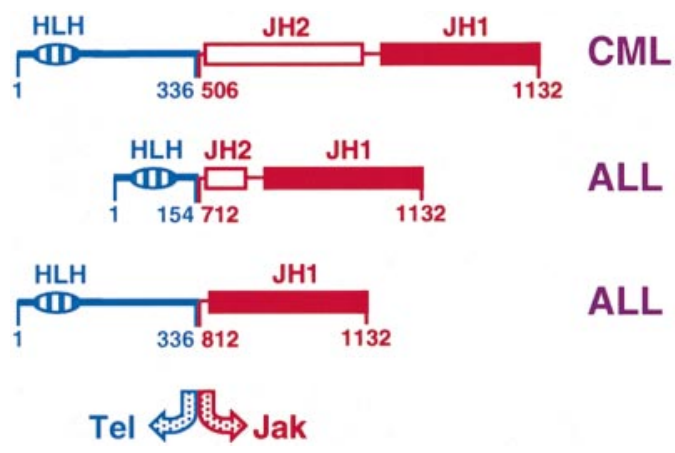

Figure 2. Tel-Jak2 fusions observed in myeloid (CML; chronic myeloid leukemia) and lymphoid (ALL; acute lymphoblastic leukemia) leukemias. ${ }^{121,122}$ The relative position of the fusions, as well as the helix-loop-helix (HLH) and Jak homology $(\mathrm{JH})$ domains are shown.
Table 5. Stat activation by specific oncoproteins

\begin{tabular}{lcll}
\hline \multicolumn{1}{c}{ Cell type } & Oncoproteins & Activated Stats & \multicolumn{1}{c}{ Refs } \\
\hline Primary bone marrow & Bcr-Abl & Stat5 & 184,185 \\
& Tel-Jak2 & Stat5 & 123,124 \\
Myeloid cells & v-Src & Stats1,3,5 & 130 \\
Basophil/mast cells & Bcr-Abl & Stats1,5 & 129,186 \\
Erythroleukemia/blast cells & Bcr-Abl & Stats1,5 & $129,186,187$ \\
Pre-B lymphocytes & v-Abl & Stats1,5,6 & 188 \\
\hline
\end{tabular}

inhibit either Stat5 activation or factor-independent cell proliferation induced by Bcr-Abl. ${ }^{129}$ In addition, v-Src can directly activate Stat $3,{ }^{130}$ whereas the Herpesvirus Tip protein co-associates Lck and Stat3, leading to constitutive Stat 3 activation in T cells transformed by this virus, ${ }^{131}$ suggesting that in these cases Jaks are also superfluous.

In contrast, numerous recent studies have provided strong evidence for a role of Stats in the transformation process. For example, a dominant-negative Stat5 was able to inhibit apoptosisresistant, growth factor-independent proliferation and leukemic potential of Bcr-Abl transformed cells ${ }^{132,133}$ and of the growth factor-independent colony formation of primary mouse bone marrow progenitor cells transduced with Bcr-Abl retrovirus. ${ }^{132}$ In addition, a constitutively active Stat5 mutant could restore these functions to a mutant Bcr-Abl deficient in Stat activation. ${ }^{132}$ Similarly, the abrogation of IL-3 dependence of myeloid cells by $\mathrm{v}-\mathrm{Src}$ requires the $\mathrm{SH} 2$ and $\mathrm{SH} 3$ domains, which specifies the activation of Stats, ${ }^{130}$ and dominant-negative Stat 3 has been shown specifically to block $\mathrm{v}$-Src transformation in other cell systems. ${ }^{134,135}$ Furthermore, studies in multiple myeloma cells that show constitutive Stat activation have revealed that dominantnegative Stat3 induces apoptosis, ${ }^{136}$ again implicating Stat 3 in the transformation process. Finally, a constitutively active mutant of Stat5 is sufficient to induce factor independence of $\mathrm{Ba} / \mathrm{F} 3$ cells. ${ }^{137}$ Thus, constitutive Stat activation appears necessary, and perhaps sufficient, for the transformation process.

The results of the above studies imply that a permanent alteration in the genetic program of transformed cells, achieved by the constitutive activation of Stat proteins, is a critical step in the transformation process. Recent studies have begun to shed light on those changes that may be important. Thus, constitutive expression of Jak2 in $\mathrm{Ba} / \mathrm{F} 3$ cells has been shown to lead to the induction of $\mathrm{Bcl}-2$, resulting in delayed cell death, ${ }^{138}$ but the constitutively activated Stat 3 observed in bone marrow mononuclear cells from patients with multiple myeloma also confers resistance to apoptosis, this time through the induction of $\mathrm{Bcl}-\mathrm{x}_{\mathrm{L}} \cdot{ }^{136}$ Identification of other genes involved in the transformation process remains an important goal for future research.

\section{Other hematologic disorders}

Alterations in the Jak-Stat pathway have been associated either directly or indirectly with other hematologic disease states.

\section{Severe combined immunodeficiency}

In the most common form of severe combined immunodeficiency (SCID), X-linked SCID, both cellular and humoral immunity are severely affected: T-cell development is arrested in the thymic cortex, there is an almost complete lack of circulating $\mathrm{T}$ lymphocytes, and, though B lymphocytes are present, they do not undergo class switching. ${ }^{139}$ In X-linked SCID, mutations have been identified in the gene encoding the common $\gamma$ chain $(\gamma c)$, a constituent of 
Table 6. Activation of Jaks and Stats in hematopoietic malignancies

\begin{tabular}{lll}
\hline \multicolumn{1}{c}{ Type of Malignancy } & Activated Jaks and Stats & \multicolumn{1}{c}{ Refs } \\
\hline Lyphoma & & \\
LSTRA T cell line & Jaks1,2; Stats3,5 & 115,189 \\
Cutaneous T-cell lymphoma & Jak3; Stats3,5 & 190 \\
Mycosis fungoides & Stat3 & 191 \\
Herpesvirus saimiri dependent & Stats1,3 & 131,192 \\
EBV-related & Stats1,3 & 193 \\
Leukemia & & \\
Erythroleukemia & Stats1,5 & 186 \\
Acute myelocytic leukemia & Stats1,3,5 & $185,193-196$ \\
Chronic myelocytic leukemia & Stat5 & 184,185 \\
Acute lymphocytic leukemia & Stats1,5 & 193,194 \\
Megakaryocytic leukemia & Stat5 & 197 \\
HTLV-I dependent T-cell leukemia & Jaks1,3; Stats3,5 & \\
\hline
\end{tabular}

EBV, Epstein-Barr virus; HTLV, human T-cell lymphoma virus.

a number of cytokine receptor complexes. ${ }^{140,141}$ Although these mutations occur at multiple positions, all mutant receptors are defective in the activation of Jak3. ${ }^{142,143}$ Indeed, Jak3 knockout mice display a SCID phenotype that is virtually indistinguishable from that of $\gamma \mathrm{c}$ null mice. ${ }^{18,144}$ Moreover, in a less common autosomal-recessive form of SCID, patients have been reported with inactivating mutations in the Jak3 gene itself., ${ }^{445,146}$ Together these findings show that abrogation of the Jak-Stat pathway is sufficient to account for SCID in humans.

\section{Severe congenital neutropenia/acute myeloid leukemia}

Patients with severe congenital neutropenia (SCN) exhibit a severe reduction in circulating neutrophils and a maturation arrest of bone marrow progenitor cells at the promyelocyte/myeloid stage. ${ }^{147,148}$ Such patients have an increased risk for myelodysplasia, acute myeloid leukemia, or both, and a poor prognosis for survival. ${ }^{149,150}$ A subset of patients with SCN has been identified with acquired nonsense mutations in the gene encoding the G-CSF receptor, which truncate its carboxyl-terminus. ${ }^{151,152}$ This subset has a strong (around 50\%) predisposition to acute myeloid leukemia. Mice carrying a similar G-CSF-R truncation also show reduced basal levels of circulating neutrophils, but on continuous G-CSF treatment, neutrophil counts become elevated to above those of wild-type controls because of the increased proliferation of myeloid progenitors. ${ }^{154}$ This suggests that the G-CSF-R truncation may contribute to SCN and to the subsequent development of acute myeloid leukemia in these patients. Bone marrow cells from these mutant mice show reduced Stat3 activation in response to G-CSF, even under saturating conditions. In addition, there is an altered dose-response of Stat 3 compared to Stat5 activation, such that at lower G-CSF concentrations the Stat 3 deficiency is even more pronounced, a result confirmed in myeloid 32D cells. ${ }^{45,155}$ Because Stat3 appears indispensable for differentiation responses to G-CSF, the reduced Stat 3:Stat5 ratio in cells with truncated receptors at low G-CSF concentrations may contribute to the reduced maturation observed. ${ }^{45,154,155}$ In addition, molecular mechanisms have been identified recently that explain the hyperproliferative function of truncated G-CSF-R. Such receptors show defective internalization compared with wild-type receptors ${ }^{46,155,156}$ and have a concomitant extension in the activation of Stats, particularly Stat $5,{ }^{46}$ consistent with a previous report of enhanced Jak2 activation in patients with SCN (Figure 3). ${ }^{157}$ It has recently been shown in 32D cells expressing truncated G-CSF-R that dominant-negative Stat5 inhibits whereas dominant-negative Stat3 actually enhances G-CSFmediated growth, implicating perturbed Stat5 activation as a key molecular determinant of the hyperproliferative responses elicited from truncated G-CSF-R (Ward et al, manuscript in preparation). In addition, a novel G-CSF-R mutation has been identified in a patient with SCN who was unresponsive to G-CSF therapy-in this case Stat5 activation was substantially reduced, ${ }^{158}$ again consistent with an important role of Stat5 in controlling proliferative responses to G-CSF.

\section{Benign erythrocytosis}

Benign erythrocytosis is a dominant autosomal condition characterized by a mild increase in red blood cell counts and normal serum levels of erythropoietin because of hypersensitivity to erythropoietin. ${ }^{159,160}$ In addition, there is an increased and a sustained activation of Jak2 and Stat5 after erythropoietin stimulation. ${ }^{112,160}$ A number of pedigrees have been identified, all of which lead to erythropoietin (EPO)-R truncations ${ }^{161,162}$ that invariably result in the loss of the binding site for SHP-1 at Tyr 449 of the EPO-R. ${ }^{112}$ Because SHP-1 is a negative regulator of Jak 2 activation by EPO, it appears that lack of SHP-1 activation is responsible for the altered Jak-Stat kinetics and enhanced EPO responses in these patients (Figure 3).

\section{Fanconi anemia}

Fanconi anemia (FA) is an autosomal recessive chromosome instability syndrome characterized by progressive bone marrow failure and an increased susceptibility to malignancy. ${ }^{163,164}$ The FA group $\mathrm{C}$ gene (FAC) has been identified, with its disruption leading to profound hypersensitivity of hematopoietic precursor cells to IFN- $\gamma$ in mice ${ }^{165}$ and in patients with FA group C. ${ }^{166}$ This appears to be the result of sustained Stat 1 activation leading to apoptosis of these cells. ${ }^{166}$ Other researchers have reported that the FAC protein is involved in the recruitment of Stat1 to the IFN- $\gamma$ receptor complex, ${ }^{167}$ which further suggests that perturbed Stat1 activation contributes to the phenotype of this disease.

\section{Interferon resistance}

Interferons, particularly IFN- $\alpha$, have important therapeutic applications in the treatment of hematologic malignancies, including CML, hairy cell leukemia, and cutaneous T-cell lymphoma (CTCL). ${ }^{168,169}$ However, the efficacy is limited by the development of clinical resistance to IFN therapy in these patients. ${ }^{169}$ Efforts to understand the molecular basis of IFN resistance have been made by generating somatic cell mutants resistant to IFN, which showed that defects in the IFN receptor, Jaks, or Stats could contribute to this phenomenon. ${ }^{21,42}$ Similar analysis of IFN- $\alpha$-resistant derivatives of CTCL cells also revealed a defect in normal Jak-Stat responses caused by a total absence of Stat1 expression, ${ }^{170}$ as previously observed in patients with IFN-resistant melanoma. ${ }^{171}$ However, a recent study also suggests a possible role for JAB in IFN resistance, especially for patients with a dominant phenotype. ${ }^{172}$ Stable expression of JAB in either NIH-3T3 or M1 leukemic cells leads to resistance to IFN- $\gamma$ - and IFN- $\beta$-induced growth arrest. In both cell systems, IFN- $\gamma$ did not induce tyrosine phosphorylation and DNA-binding activity of Stat1. In addition, IFN-resistant clones derived from LoVo cells and Daudi cells were found to express high endogenous levels of JAB without stimulation, with a concomitant reduction in IFN-induced Stat1 and Jak phosphorylation. ${ }^{172}$ 
Figure 3. Mechanisms of aberrant Stat activation in hematopoietic malignancy and disease.

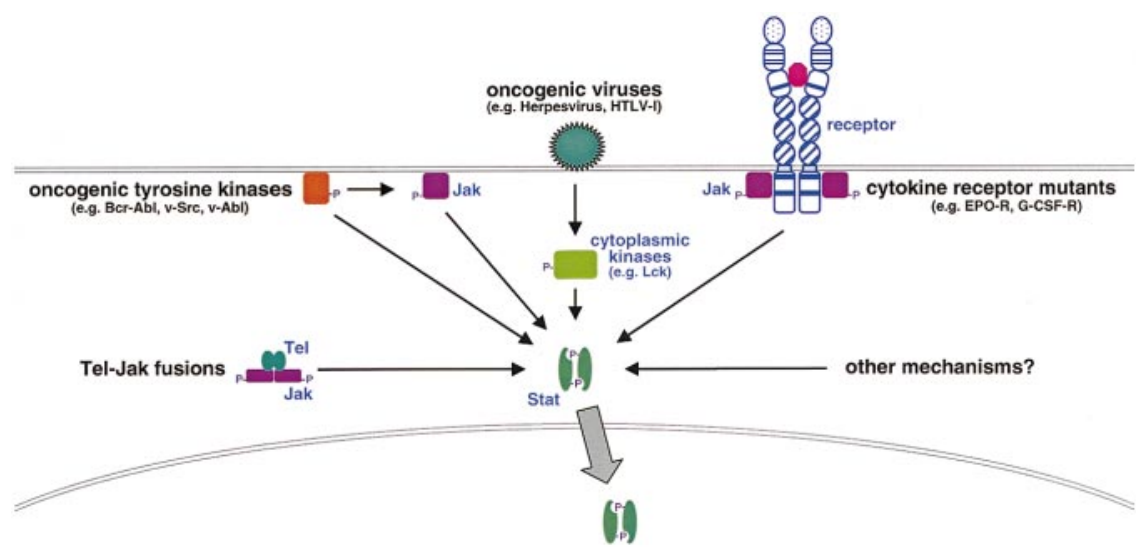

\section{Other diseases with altered Jak-Stat activation}

Other hematologic diseases also show defects in the normal activation and regulation of Jak-Stat pathway components. For example, bone marrow cells from patients with myelodysplastic syndrome show impaired erythropoietin-induced Stat5 activation, ${ }^{173}$ whereas reduced Tyk2/SHP-1 interaction has been observed in a kindred of familial hemophagocytic lymphohistiocytosis. ${ }^{174}$ However, additional experiments will be required to identify mechanisms by which these perturbations in the Jak-Stat pathway may contribute to the pathogenesis of disease.

\section{Future directions}

It is clear from this review that the Jak-Stat pathway is perturbed in a variety of malignancies and hematopoietic disorders. There is also now solid evidence that constitutive activation of Jak-Stat pathway components plays an important role in transformation by Tel-Jak, Bcr-Abl, and v-Src and in multiple myeloma. Furthermore, the importance of defective Jak3 activation in SCID and of extended Stat5 activation in the hyperproliferative responses of truncated G-CSF-R is now established. However, the significance of altered Jak-Stat activation in the other disorders remains less clear. In each case, the judicious expression of dominant-negative or constitutively active Jak-Stat pathway components in either cell line or mouse models of these disorders should enable the relative contribution of altered Jak-Stat signaling to the disease phenotype to be established. In addition, the availability of numerous mouse strains either deficient or transgenic for specific Jak-Stat components provides additional opportunity for assessing their importance in vivo.

\section{Conclusions}

Much remains to be learned about structure/function relationships of Jaks and Stats and about the cross talk between the Jak-Stat pathway and other signaling pathways in hematopoietic cells. In addition, as outlined above, the definitive roles played by Stats in growth control and transformation must be determined. Furthermore, a complete understanding of the mechanisms by which the Jak-Stat pathway is negatively regulated remains an important goal. However, there is already much promise in applying the knowledge obtained on the Jak-Stat pathway and its perturbation for the development of innovative hematologic treatment strategies. As mentioned above, specific Jak inhibitors may have important clinical applications in acute lymphoblastic leukemia, ${ }^{128}$ and there is clear potential for using gene therapy to remedy Jak3 deficiency in SCID. ${ }^{175,176}$ Recent data providing the crystallographic structure of Stat1 and Stat3 complexed with DNA ${ }^{177,178}$ opens the way for a finer understanding of Stat specificity at the molecular level, increasing the knowledge base required for designing suitable compounds for pharmacologic intervention. It is anticipated that future developments will further facilitate the translation of the basic science of the Jak-Stat pathway into the hematology clinic.

\section{Acknowledgment}

The authors apologize to colleagues whose works were not cited because of the size restrictions of the review.

\section{References}

1. Taniguchi T. Cytokine signaling through nonreceptor protein tyrosine kinases. Science. 1995; 268:251-255.

2. Ihle JN. Signaling by the cytokine receptor superfamily in normal and transformed hematopoietic cells. Adv Cancer Res. 1996;68:23-65.

3. Wells JA, de Vos AM. Hematopoietic receptor complexes. Annu Rev Biochem. 1996;65:609-634.

4. Cacalano NA, Migone TS, Bazan F, et al. Autosomal SCID caused by a point mutation in the $\mathrm{N}$ terminus of Jak3: mapping of the Jak3-receptor interaction domain. EMBO J. 1999;18:1549-1558.

5. Novak U, Harpur AG, Paradiso L, et al. CSF-1 induced STAT activation is accompanied by phos- phorylation of Tyk2 in macrophages and Tyk2 and JAK1 in fibroblasts. Blood. 1995;86:2948-2956.

6. Deberry C, Mou S, Linnekin D. Stat1 associates with c-kit and is activated in response to stem cell factor. Biochem J. 1997;327:73-80.

7. Müller M, Briscoe J, Laxton C, et al. The protein tyrosine kinase JAK1 complements defects in interferon $\alpha / \beta$ and $-\gamma$ signal transduction. Nature. 1993;366:129-135.

8. Watling D, Guschin D, Muller M, et al. Complementation by the protein tyrosine kinase JAK2 of a mutant cell line defective in interferon-gamma signal transduction. Nature. 1993;366:166-170.

9. Velazquez L, Fellous M, Stark GR, Pellegrini S. A protein tyrosine kinase in the interferon alpha/ beta signaling pathway. Cell. 1992;70:313-322.

10. Miura O, Cleveland JL, Ihle JN. Inactivation of erythropoietin receptor function by point mutations in a region having homology with other cytokine receptors. Mol Cell Biol. 1993;13:1788-1795.

11. Quelle FW, Sato N, Witthuhn BA, et al. Jak2 associates with the $\beta_{c}$ chain of the receptor for granulocyte-macrophage colony-stimulating factor, and its activation requires the membrane-proximal region. Mol Cell Biol. 1994;14:4335-4341.

12. Zhuang H, Niu Z, He TC, Patel SV, Wojchowski DM. Erythropoietin-dependent inhibition of apoptosis is supported by carboxyl-truncated receptor 
forms and blocked by dominant-negative forms of Jak2. J Biol Chem. 1995;270:14500-14504.

13. Barge RM, de Koning JP, Pouwels K, Dong F, Löwenberg B, Touw IP. Tryptophan 650 of human granulocyte colony-stimulating factor (G-CSF) receptor, implicated in the activation of JAK2, is also required for G-CSF-mediated activation of signaling complexes of the p21 ras route. Blood. 1996;87:2148-2153.

14. Nicholson SE, Willson TA, Farley A, et al. Mutational analyses of the SOCS proteins suggest a dual domain requirement but distinct mechanisms for inhibtion of LIF and IL-6 signal transduction. EMBO J. 1999;18:375-385

15. Rodig SJ, Meraz MA, White JM, et al. Disruption of the Jak1 gene demonstrates obligatory and nonredundant roles of the Jaks in cytokine-induced biologic responses. Cell. 1998;93:373-383.

16. Parganas E, Wang D, Stravopodis D, et al. Jak2 is essential for signaling through a variety of cytokine receptors. Cell. 1998;93:385-395.

17. Neubauer H, Cumano A, Muller M, Wu H, Huffstadt U, Pfeffer K. Jak2 deficiency defines an essential developmental checkpoint in definitive hematopoiesis. Cell.1998;93:397-409.

18. Nosaka T, van Deursen JM, Tripp RA, et al. Defective lymphoid development in mice lacking Jak3. Science. 1995;270:800-802.

19. Park SY, Saijo K, Takahashi T, et al. Developmental defects of lymphoid cells in Jak3 kinase-deficient mice. Immunity. 1995;3:771-782.

20. Grossman WJ, Verbsky JW, Yang L, et al. Dysregulated myelopoiesis in mice lacking Jak3. Blood. 1999;94:932-939.

21. Darnell JE Jr. STATs and gene regulation. Science. 1997;277:1630-1635.

22. Meraz MA, White JM, Sheehan KCF, et al. Targeted disruption of the Stat1 gene in mice reveals unexpected physiologic specificity in the JAKSTAT signaling pathway. Cell. 1996;84:431-442.

23. Durbin JE, Hackenmiller R, Simon MC, Levy DE. Targeted disruption of the mouse Stat1 gene results in compromised innate immunity to viral disease. Cell. 1996;85:443-450.

24. Takeda K, Noguchi K, Shi W, et al. Targeted disruption of the mouse Stat3 gene leads to early embryonic lethality. Proc Natl Acad Sci U S A 1997; $94: 3801-3804$

25. Takeda K, Kaisho T, Yoshida N, Takeda J, Kishimoto T, Akira S. Stat3 activation is responsible for IL-6-dependent T cell proliferation through preventing apoptosis: generation and characterization of T cell-specific Stat3-deficient mice. J Immunol. 1998;161:4652-4660.

26. Thierfelder WE, Van Deursen J, Yamamoto K, et al. Requirement for Stat4 in interleukin-12 mediated responses of natural killer cells. Nature. 1996;382:171-174.

27. Kaplan MH, Sun YL, Hoey T, Grusby MJ. Impaired IL-12 responses and enhanced development of Th2 cells in Stat4-deficient mice. Nature. 1996;382:174-177

28. Teglund S, McKay C, Schuetz E, et al. Stat5a and Stat5b proteins have essential and nonessential, or redundant, roles in cytokine responses. Cell. 1998;93:841-850.

29. Moriggl R, Topham DJ, Teglund S, et al. Stat5 is required for IL-2-induced cell cycle progression of peripheral T cells. Immunity. 1999;10:249-259.

30. Feldman GM, Rosenthal LA, Liu X, et al. STAT5A-deficient mice demonstrate a defect in granulocyte-macrophage colony-stimulating factor-induced proliferation and gene expression. Blood. 1997:90:1768-1776.

31. Imada K, Bloom ET, Nakajima $H$, et al. Stat5b is essential for natural killer cell-mediated proliferation and cytolytic activity. J Exp Med. 1998;188: 2067-2074.

32. Takeda K, Tanaka T, Shi W, et al. Essential role of Stat6 in IL-4 signalling. Nature. 1996;380:627630.
33. Shimoda K, van Deursen J, Sangster MY, et al. Lack of IL-4 induced Th2 response and IgE class switching in mice with disrupted Stat6 gene. $\mathrm{Na}$ ture. 1996;380:630-633.

34. Müller M, Laxton C, Briscoe J, et al. Complementation of a mutant cell line: central role of the 91 kDa polypeptide of ISGF3 in the interferon- $\alpha$ and $-\gamma$ signal transduction pathways. EMBO J. 1993; 12:4221-4228.

35. Nakajima K, Yamanaka Y, Nakae K, et al. A central role for Stat3 in IL-6-induced regulation of growth and differentiation in M1 leukemia cells. EMBO J. 1996:15:3651-3658.

36. Shimozaki K, Nakajima K, Hirano T, Nagata S Involvement of STAT3 in the granulocyte colonystimulating factor-induced differentiation of myeloid cells. J Biol Chem. 1997;272:25,18425,189.

37. Ward AC, Smith L, de Koning JP, van Aesch Y, Touw IP. Multiple signals mediate proliferation, differentiation and survival from the granulocyte colony-stimulating factor receptor in myeloid 32D cells. J Biol Chem. 1999;274:14,956-14,962.

38. Mui AL-F, Wakao H, O'Farrell A-M, Harada N, Miyajima A. Interleukin-3, granulocyte-macrophage colony stimulating factor and interleukin- 5 transduce signals through two STAT5 homologs. EMBO J. 1995;14:1166-1175.

39. Dong F, Liu X, de Koning JP, et al. Stimulation of Stat 5 by granulocyte colony-stimulating factor (G-CSF) is modulated by two distinct cytoplasmic regions of the G-CSF receptor. J Immunol. 1998; 161:6503-6509.

40. Ilaria RL Jr, Hawley RG, Van Etten RA. Dominant negative mutants implicate STAT5 in myeloid cell proliferation and neutrophil differentiation. Blood.1999;93:4154-4166.

41. Horvath CM, Darnell JE Jr. The state of the STATs: recent developments in the study of signa transduction to the nucleus. Curr Opin Cell Biol. 1997;9:233-239.

42. Darnell JE Jr, Kerr IM, Stark GR. JAK-STAT pathways and transcriptional activation in response to interferons and other extracellular signalling proteins. Science. 1994;264:1415-1421.

43. O'Shea JJ. Jaks, STATs, cytokine signal transduction, and immunoregulation: are we there yet? Immunity. 1997;7:1-11.

44. Schindler C, Darnell JE Jr. Transcriptional responses to polypeptide ligands: the JAK-STAT pathway. Annu Rev Biochem. 1995;64:621-651.

45. Ward AC, Hermans MHA, Smith L, et al. Tyrosine-dependent and independent mechanisms of STAT3 activation by the human granulocyte colony-stimulating factor (G-CSF) receptor are differentially utilized depending on G-CSF concentration. Blood. 1999:93:113-124.

46. Ward AC, van Aesch YM, Schelen AM, Touw IP. Defective internalization and sustained activation of truncated granulocyte colony-stimulating factor receptor found in severe congenital neutropenia/ acute myeloid leukemia. Blood. 1999;93:447-458.

47. Ihle JN, Kerr IM. Jaks and Stats in signaling by the cytokine receptor superfamily. Trends Genet. 1995:11:69-74.

48. Heim MH, Kerr IM, Stark GR, Darnell JE Jr. Contribution of STAT SH2 groups to specific interferon signaling by the Jak-STAT pathway. Science. 1995;267:1347-1349.

49. Hou J, Schindler U, Henzel WJ, Ho TC, Brasseur M, McKnight SL. An interleukin-4-induced transcription factor: IL-4 Stat. Science. 1994;265: 1701-1706.

50. Stahl N, Farruggella TJ, Bolton TG, Zhong Z, Darnell JE, Yancopoulos GD. Choice of STATs and other substrates specified by modular tyrosinebased motifs in cytokine receptors. Science. 1995;267:1349-1353.

51. de Koning JP, Dong F, Smith L, et al. The membrane-distal cytoplasmic region of human granu- locyte colony-stimulating factor receptor is required for STAT3 but not STAT1 homodimer formation. Blood. 1996;87:1335-1342.

52. Wang YD, Wong K, Wood WI. Intracellular tyrosine residues of the human growth hormone receptor are not required for the signaling of proliferation or Jak-STAT activation. J Biol Chem. 1995;270:7021-7024.

53. Shuai K, Stark GR, Kerr I, Darnell JE Jr. A single phosphotyrosine residue of Stat91 required for gene activation by interferon- $\gamma$. Science. 1993; 261:1744-1746.

54. Wakao H, Gouilleux F, Groner B. Mammary gland factor (MGF) is a novel member of the cytokine regulated transcription factor gene family and confers the prolactin response. EMBO J. 1994; 13:2182-2191.

55. Shimoda K, Feng J, Murakami H, et al. Jak1 plays an essential role for receptor phosphorylation and Stat activation in response to granulocyte colony-stimulating factor. Blood. 1997;90: 597-604.

56. Avalos BR, Parker JM, Ware DA, Hunter MG, Sibert KA, Druker BJ. Dissociation of the Jak kinase pathway from G-CSF receptor signaling in neutrophils. Exp Hematol. 1997;25:160-168.

57. Caldenhoven E, van Dijk TB, Raaijmakers JAM, Lammers J-WJ, Koenderman L, de Groot RP. Activation of a functionally distinct $80-\mathrm{kDa}$ STAT5 isoform by IL-5 and GM-CSF in human eosinophils and neutrophils. Mol Cell Biol Res Comm. 1999;1:95-101.

58. Caldenhoven E, Buitenhuis M, van Dijk TB, et al. Lineage-specific activation of STAT3 by interferon-gamma in human neutrophils. $\mathrm{J}$ Leukoc Biol. 1999;65:391-396.

59. Castro A, Sengupta TK, Ruiz DC, Yang E, Ivashkiv LB. IL-4 selectively inhibits IL-2-triggered Stat5 activation, but not proliferation, in human $\mathrm{T}$ cells. J Immunol. 1999;162:1261-1269.

60. Ito S, Ansari P, Sakatsume M, et al. Interleukin-10 inhibits expression of both interferon alpha- and interferon gamma-induced genes by suppressing tyrosine phosphorylation of STAT1. Blood. 1999; 93:1456-1463.

61. Kolenko V, Rayman P, Roy B, et al. Downregulation of JAK3 protein levels in T lymphocytes by prostaglandin $\mathrm{E}_{2}$ and other cyclic adenosine monophosphate-elevating agents: impact on interleukin-2 receptor signaling pathway. Blood. 1999;93:2308-2318.

62. Lamb P, Seidel HM, Haslam J, et al. STAT protein complexes activated by interferon- $\gamma$ and gp130 signaling molecules differ in their sequence preferences and transcriptional induction properties. Nucl Acids Res. 1995;23:3283-3289.

63. Seidel HM, Milocco LH, Lamb P, Darnell JE Jr, Stein RB, Rosen J. Spacing of palindromic half sites as a determinant of selective STAT (signal transducers and activators of transcription) DNA binding and transcriptional activity. Proc Natl Acad Sci U S A. 1995;92:3041-3045.

64. Decker T, Kovarik P, Meinke A. GAS elements: a few nucleotides with a major impact on cytokineinduced gene expression. J Interferon Cytokine Res. 1997;17:121-134.

65. Caldenhoven E, van Dijk TB, Solari R, et al. STAT3 beta, a splice variant of transcription factor STAT3, is a dominant-negative regulator of transcription. J Biol Chem. 1996;271:13,221-13,227.

66. Luo G, Yu-Lee L. Transcriptional inhibition by Stat5: differential activities at growth-related versus differentiation-specific promoters. J Biol Chem. 1997;272:26,841-26,849.

67. Schaefer TS, Sanders LK, Nathans D. Cooperative transcriptional activity of Jun and Stat3 beta a short form of Stat3. Proc Natl Acad Sci U S A. 1995;92:9097-9101.

68. Zhang JJ, Zhao Y, Chait BT, et al. Ser727-dependent recruitment of MCM 5 by Stat $1 \alpha$ in IFN- $\gamma$ - 
induced transcriptional activation. EMBO J. 1998; 17:6963-6971.

69. Zhu M-H, John S, Berg M, Leonard WJ. Functional association of Nmi with Stat5 and Stat1 in IL-2- and IFN $\gamma$-mediated signaling. Cell. 1999;96: 121-130.

70. Wen Z, Zhong Z, Darnell JE Jr. Maximal activation of transcription by Stat 1 and Stat3 requires both tyrosine and serine phosphorylation. Cell. 1995;82:241-250.

71. Zhang X, Blenis J, Li H-C, Schindler C, ChenKiang S. Requirement of serine phosphorylation for formation of STAT-promoter complexes. Science. 1995;267:1990-1994.

72. Chung CD, Liao J, Liu B, et al. Specific inhibition of Stat3 signal transduction by PIAS3. Science. 1997;278:1803-1805.

73. Jain N, Zhang T, Fong SL, Lim CP, Cao X. Repression of Stat3 activity by activation of mitogenactivated protein kinase. Oncogene. 1998;17: 3157-3167.

74. Miyazaki T, Takaoka A, Nogueira L, et al. Pyk2 is a downstream mediator of the IL-2 receptorcoupled Jak signaling pathway. Genes Dev. 1998; 12:770-775.

75. Schiemann WP, Bartoe JL, Nathanson NM. Box 3-independent signaling mechanisms are involved in leukemia inhibitory factor receptor alpha- and gp130-mediated stimulation of mitogenactivated protein kinase: evidence for participation of multiple signaling pathways which converge at Ras. J Biol Chem. 1997;272:16,63116,636 .

76. Mizuguchi R, Hatakeyama M. Conditional activation of Janus kinase (JAK) confers factor independence upon interleukin-3-dependent cells: essential role of Ras in JAK-triggered mitogenesis. J Biol Chem. 1998;273:32,297-32,303.

77. Watanabe S, Itoh T, Arai K. Roles of JAK kinase in human GM-CSF receptor signals. Leukemia. 1997;11(suppl 3):76-78.

78. Karras JG, Wang Z, Huo L, Frank DA, Rothstein TL. Induction of STAT protein signaling through the CD40 receptor in B lymphocytes: distinct STAT activation following surface Ig and CD40 receptor engagement. J Immunol. 1997;159: 4350-4355.

79. Cao X, Tay A, Guy GR, Tan YH. Activation and association of Stat3 with Src in v-Src-transformed cell lines. Mol Cell Biol. 1996;16:1595-1603.

80. Rhodes J, York RD, Tajinda K, Tara D, Druker BJ. Analysis of CrkL and Stat5 interactions in BcrAbl-expressing cells [abstract]. Blood. 1998;92: 476a.

81. Yamashita H, Xu J, Erwin RA, Farrar WL, Kirken RA, Rui H. Differential control of the phosphorylation state of proline-juxtaposed serine residues Ser725 of Stat5a and Ser730 of Stat5b in prolactin-sensitive cells. J Biol Chem. 1998;273:3021830224.

82. Kim TK, Maniatis T. Regulation of interferongamma-activated STAT1 by the ubiquitin-proteasome pathway. Science. 1996;273:1717-1719.

83. Strous GJ, van Kerkhof P, Govers R, Ciechanover A, Schwartz AL. The ubiquitin conjugation system is required for ligand-induced endocytosis and degradation of the growth hormone receptor. EMBO J. 1996;15:3806-3812.

84. Wang D, Stravopodis D, Teglund S, Kitazawa J, Ihle JN. Naturally occurring dominant negative variants of Stat5. Mol Cell Biol. 1996;16:6141 6148.

85. Azam M, Lee C, Strethlow I, Schindler C. Functionally distinct isoforms of STAT5 are generated by protein processing. Immunity. 1997;6:691-701.

86. Liu B, Liao J, Rao X, et al. Inhibition of Stat1-mediated gene activation by PIAS1. Proc Natl Acad Sci U S A. 1998;95:10,626-10,631.

87. Masuhara M, Sakamoto $H$, Matsumoto A, et al. Cloning and characterization of novel CIS family genes. Biochem Biophys Res Comm. 1997;239: 439-446.

88. Hilton DJ, Richardson RT, Alexander WS, et al. Twenty proteins containing a C-terminal SOCS box form five structural classes. Proc Natl Acad Sci U S A. 1998;95:114-119.

89. Yoshimura A. The CIS family: negative regulators of JAK-STAT signaling. Cytokine Growth Factor Rev. 1998;9:197-204.

90. Yoshimura A, Ohkubo T, Kiguchi T, et al. A novel cytokine-inducible gene $\mathrm{CIS}$ encodes an $\mathrm{SH} 2$ containing protein that binds to tyrosine-phos phorylated interleukin 3 and erythropoietin receptors. EMBO J. 1995;14:2816-2826.

91. Uchida K, Yoshimura A, Inazawa J, et al. Molecular cloning of $\mathrm{CISH}$, chromosomal assignment to 3 p21.3, and analysis of expression in fetal and adult tissues. Cytogenet Cell Genet.1997;78:209212

92. Matsumoto A, Masuhara M, Mitsui K, et al. CIS, a cytokine inducible $\mathrm{SH} 2$ protein, is a target of the JAK-STAT5 pathway and modulates STAT5 activation. Blood. 1997;89:3148-3154.

93. Verdier F, Chretien S, Muller O, et al. Proteasomes regulate erythropoietin receptor and STAT5 activation: possible involvement of the ubiquitinated CIS protein. J Biol Chem. 1998;273: 28,185-28,190.

94. Matsumoto A, Seki Y, Kubo M, et al. Suppression of STAT5 functions in liver, mammary glands, and T cells in cytokine-inducible SH2 protein-1 (CIS1) transgenic mice. Mol Cell Biol. 1999;19:63966407.

95. Endo TA, Masuhara M, Yokouchi M, et al. A new protein containing an $\mathrm{SH} 2$ domain that inhibits JAK kinases. Nature. 1997;387:921-924.

96. Ohya KI, Kajigaya S, Yamashita Y, et al. SOCS-1/ JAB/SSI-1 can bind to and suppress Tec proteintyrosine kinase. J Biol Chem. 1997;272:2717827182.

97. Starr R, Wilson TA, Viney EM, et al. A family of cytokine-inducible inhibitors of signalling. Nature. 1997;387:917-921.

98. Naka T, Narazaki M, Hirata M, et al. Structure and function of a new STAT-induced STAT inhibitor. Nature. 1997;387:924-929.

99. De Sepulveda P, Okkenhaug K, Rose JL, Hawley RG, Dubreuil P, Rottapel R. Socs1 binds to multiple signalling proteins and suppresses Steel factor-dependent proliferation. EMBO J. 1999;18: 904-915.

100. Naka T, Matsumoto T, Narazaki M, et al. Accelerated apoptosis of lymphocytes by augmented in duction of Bax in SSI-1 (STAT-induced STAT inhibitor-1) deficient mice. Proc Natl Acad Sci U S A. 1998;95:15,577-15,582

101. Starr R, Metcalf D, Elefanty AG, et al. Liver degeneration and lymphoid deficiencies in mice lacking suppressor of cytokine signaling-1. Proc Natl Acad Sci U S A. 1998;95:14,395-14,399.

102. Young HA, Klinman DM, Reynolds DA, et al. Bone marrow and thymus expression of interferon-gamma results in severe B-cell lineage reduction, T-cell lineage alterations, and hematopoietic progenitor deficiencies. Blood. 1997;89: 583-595.

103. Metcalf D, Alexander WS, Elefanty AG, et al. Aberrant hematopoiesis in mice with inactivation of the gene encoding SOCS-1. Leukemia. 1999;13: 926-934.

104. Nicola NA, Nicholson S, Metcalf D, et al. Negative regulation of cytokine signaling by SOCS proteins [abstract]. LXIV Cold Spring Harbor Symposium on Quantitative Biology. 1999:237a.

105. Yasukawa $\mathrm{H}$, Misawa $\mathrm{H}$, Sakamoto $\mathrm{H}$, et al. The JAK-binding protein JAB inhibits Janus tyrosine kinase activity through binding in the activation loop. EMBO J. 1999;18:1309-1320.

106. Liu KD, Gaffen SL, Goldsmith MA, Greene WC. Janus kinases in interleukin-2-mediated signaling: JAK1 and JAK3 are differentially regulated by tyrosine phosphorylation. Curr Biol.1997;7:817826.

107. Weiss A, Schlessinger J. Switching signals on or off by receptor dimerization. Cell. 1998;94:277280.

108. Kamura T, Sato S, Haque D, et al. The elongin $\mathrm{BC}$ complex interacts with the conserved SOCS box motif present in members of the SOCS, ras, WD-40 repeat, and ankyrin repeat families. Genes Dev. 1998;12:3872-3881.

109. Zhang J-G, Farley A, Nicholson SE, et al. The conserved SOCS box motif in suppressors of cytokine signaling binds to elongins $\mathrm{B}$ and $\mathrm{C}$ and may couple bound proteins to proteasomal degradation. Proc Natl Acad Sci U S A. 1999;96: 2071-2076

110. Tyers $M$, Willems AR. One ring to rule a superfamily of E3 ubiquitin ligases. Science. 1999;284: 603-604.

111. Narazaki M, Fujimoto $M$, Matsumoto $T$, et al. Three distinct domains of SSI-1/SOCS-1/JAB protein are required for its suppression of interleukin 6 signaling. Proc Natl Acad Sci U S A. 1998; $95: 13,130-13,134$

112. Klingmüller U, Lorenz U, Cantley LC, Neel BG Lodish HF. Specific recruitment of SH-PTP1 to the erythropoietin receptor causes inactivation of JAK2 and termination of proliferative signals. Cell. 1995;80:729-738.

113. Fuhrer DK, Feng G-S, Yang Y-C. Syp associates with gp130 and Janus Kinase 2 in response to interleukin-11 in 3T3-L1 mouse preadipocytes. J Biol Chem. 1995;270:24,826-24,830.

114. Jiao H, Berrada K, Yang W, Tabrizi M, Platanias LC, Yi T. Direct association with and dephosphorylation of Jak2 kinase by the SH2-domaincontaining protein tyrosine phosphatase SHP-1. Mol Cell Biol. 1996;16:6985-6992.

115. You M, Yu D-H, Feng G-S. Shp-2 tyrosine phosphatase functions as a negative regulator of the interferon-stimulated Jak-STAT pathway. Mol Cell Biol. 1999;19:2416-2424.

116. Carpenter LR, Farruggella TJ, Symes A, Karow ML, Yancopoulos GD, Stahl N. Enhancing leptin responses by preventing $\mathrm{SH} 2$-containing phosphatase 2 interaction with $\mathrm{Ob}$ receptor. Proc Nat Acad Sci U S A. 1998;95:6061-6066.

117. Shultz LD, Schweitzer PA, Rajan TV, et al. Mutations at the murine motheaten locus are within the hematopoietic cell protein-tyrosine phosphatase (Hcph) gene. Cell. 1993;73:1445-1454.

118. Plas DR, Johnson R, Pingel JT, et al. Direct regulation of ZAP-70 by SHP-1 in T cell antigen receptor signaling. Science. 1996;272:1173-1176.

119. Kozlowski M, Larose L, Lee F, Le DM, Rottapel R, Siminovitch KA. SHP-1 binds and negatively modulates the c-Kit receptor by interaction with tyrosine 569 in the c-Kit juxtamembrane domain Mol Cell Biol. 1998;18:2089-2099.

120. Ram PA, Waxman DJ. Interaction of growth hormone-activated STATs with SH2-containing phosphotyrosine phosphatase SHP-1 and nuclear JAK2 tyrosine kinase. J Biol Chem. 1997;272: 17,694-17,702.

121. Lacronique V, Boureux A, Valle VD, et al. A TELJAK2 fusion protein with constitutive kinase activity in human leukemia. Science. 1997;278:13091312.

122. Peeters P, Raynaud SD, Cools J, et al. Fusion of TEL, the ETS-variant gene 6 (ETV6), to the receptor-associated kinase JAK2 as a result of $t(9$; $12)$ in a lymphoid and $t(9 ; 15 ; 12)$ in a myeloid leukemia. Blood. 1997;90:2535-2540.

123. Schwaller J, Frantsve J, Aster J, et al. Transformation of hematopoietic cell lines to growth-factor independence and induction of a fatal myelo- and lymphoproliferative disease in mice by retrovirally transduced TEL/JAK2 fusion genes. EMBO J. 1998;17:5321-5333.

124. Ho JM-Y, Beattie BK, Squire JA, Frank DA, Barber DL. Fusion of the ets transcription factor TEL 
to Jak2 results in constitutive Jak-Stat signaling Blood. 1999;93:4354-4364.

125. Garcia R, Jove R. Activation of STAT transcription factors in oncogenic tyrosine kinase signaling. $\mathrm{J}$ Biomed Sci.1998:5:79-85.

126. Harrison DA, Binari R, Nahreini TS, Gilman M, Perrimon N. Activation of a Drosophila Janus kinase (JAK) causes hematopoietic neoplasia and developmental defects. EMBO J. 1995;14:28572865.

127. Luo H, Rose P, Barber D, et al. Mutation in the Jak kinase $\mathrm{JH} 2$ domain hyperactivates $D r o-$ sophila and mammalian Jak-Stat pathways. Mol Cell Biol. 1997;17:1562-1571.

128. Meydan N, Grunberger T, Dadi H, et al. Inhibition of acute lymphoblastic leukaemia by a Jak-2 inhibitor. Nature. 1996;379:645-648.

129. Ilaria RL Jr, Van Etten RA. P210 and P190 (BCR/ $A B L$ ) induce the tyrosine phosphorylation and DNA binding activity of multiple specific STAT family members. J Biol Chem. 1996;271:31,70431,710 .

130. Chaturvedi P, Sharma S, Reddy EP. Abrogation of interleukin-3 dependence of myeloid cells by the $\mathrm{v}$-src oncogene requires $\mathrm{SH} 2$ and $\mathrm{SH} 3$ domains which specify activation of STATs. Mol Cell Biol. 1997; 17:3295-3304.

131. Lund TC, Prator PC, Medveczky MM, Medveczky $P G$. The Lck binding domain of herpesvirus saimiri tip-484 constitutively activates Lck and STAT3 in T cells. J Virol. 1999;73:1689-1694.

132. Nieborowska-Skorska M, Wasik MA, Slupianek A et al. Signal transducer and activator of transcription (STAT) 5 activation by $\mathrm{BCR} / \mathrm{ABL}$ is dependent on intact Srh homology $(\mathrm{SH}) 3$ and $\mathrm{SH} 2$ domains of $B C R / A B L$ and is required for leukemogenesis. J Exp Med. 1999;189:1229-1242.

133. de Groot RP, Raaijmakers JAM, Lammers J-WJ, Jove R, Koenderman L. STAT5 activation by BCR-Abl contributes to transformation of K562 leukemia cells. Blood. 1999;94:1108-1112.

134. Turkson J, Bowman T, Garcia R, Caldenhoven E, de Groot RP, Jove R. Stat3 activation by Src induces specific gene regulation and is required for cell transformation. Mol Cell Biol. 1998;18:25452552.

135. Bromberg JF, Horvath CM, Besser D, Lathem WW, Darnell JE Jr. Stat3 activation is required for cellular transformation by v-src. Mol Cell Biol. 1998; 18:2553-2558

136. Catlett-Falcone R, Landowski TH, Oshiro MM, et al. Constitutive activation of Stat3 signaling confers resistance to apoptosis in human U266 myeloma cells. Immunity. 1999;10:105-115.

137. Onishi M, Nosaka T, Misawa K, et al. Identification and characterization of a constitutively active STAT5 mutant that promotes cell proliferation. Mol Cell Biol. 1998;18:3871-3879.

138. Sakai I, Kraft AS. The kinase domain of Jak2 mediates induction of bcl-2 and delays cell death in hematopoietic cells. J Biol Chem. 1997;272: 12,350-12,358.

139. Voss SD, Hong R, Sondel PM. Severe combined immunodeficiency, interleukin-2 (IL-2), and the IL-2 receptor: experiments of nature continue to point the way. Blood. 1994;83:626-635.

140. Noguchi M, Yi H, Rosenblatt HM, et al. Interleukin-2 receptor $\gamma$ chain mutation results in $\mathrm{X}$-linked severe combined immunodeficiency in humans. Cell. 1993;73:147-157.

141. Puck JM, Deschenes SM, Porter JC, et al. The interleukin-2 receptor gamma chain maps to $\mathrm{Xq} 13.1$ and is mutated in severe combined immu nodeficiency, SCIDX1. Hum Mol Genet. 1993;2: 1099-1104.

142. Johnston JA, Kawamura M, Kirken RA, et al. Phosphorylation and activation of the Jak-3 kinase in response to interleukin-2. Nature. 1994; 370:151-153.
143. Pepper AE, Buckley RH, Small TN, Puck JM. Two mutational hotspots in the interleukin-2 receptor gene causing human $\mathrm{X}$-linked severe combined immunodeficiency. Am J Hum Genet. 1995;57: 564-571.

144. Disanto JP, Muller W, GuyGrand D, Fischer A, Rajewsky K. Lymphoid development in mice with a targeted deletion of the interleukin 2 receptor $\gamma \mathrm{c}$ chain. Proc Natl Acad Sci U S A. 1995;92:377 381.

145. Russell SM, Tayebi N, Nakajima H, et al. Mutation of JAK3 in a patient with SCID: essential role of JAK3 in lymphoid development. Science. 1995; 270:797-800.

146. Macchi P, Villa A, Gillani S, et al. Mutations of Jak-3 gene in patients with autosomal severe combined immunodeficiency (SCID). Nature. 1995;377:65-68.

147. Kostmann R. Infantile genetic agranulocytosis. Acta Paediatr. 1956;45(suppl 105):1-78.

148. Kawaguchi Y, Kobayashi M, Tanabe A, et al. Granulopoiesis in patients with congenital neutropenia. Am J Hematol. 1985;20:223-234.

149. Gillio AP, Gabrilove JL. Cytokine treatment of in herited bone marrow failure syndromes. Blood. 1993;81:1669-1674.

150. Kalra R, Dale D, Freedman M, et al. Monosomy 7 and activating RAS mutations accompany malignant transformation in patients with congenital neutropenia. Blood. 1995;86:4579-4586.

151. Dong F, Brynes RK, Tidow N, Welte K, Löwenberg B, Touw IP. Mutations in the gene for the granulocyte colony-stimulating-factor receptor in patients with acute myeloid leukemia preceded by severe congenital neutropenia. N Engl J Med. 1995;333:487-493

152. Dong F, Dale DC, Bonilla MA, et al. Mutations in the granulocyte colony-stimulating factor recepto gene in patients with severe congenital neutropenia. Leukemia. 1997;11:120-125.

153. Welte K, Touw IP. G-CSF receptor mutations in patients with severe chronic neutropenia: a step in leukemogenesis [abstract]. Blood. 1997;90 433a.

154. Hermans MHA, Ward AC, Antonissen C, Karis A, Lowenberg B, Touw IP. Perturbed granulopoiesis in mice with a targeted mutation in the granulocyte colony-stimulating factor receptor gene associated with severe chronic neutropenia. Blood. 1998;92:32-39.

155. Hermans MHA, Antonissen C, Ward AC, Mayen AEM, Ploemacher RE, Touw IP. Sustained receptor activation and hyperproliferation in response to granulocyte colony-stimulating factor (G-CSF) in mice with a severe congenital neutropenia/ acute myeloid leukemia-derived mutation in the G-CSF receptor gene. J Exp Med. 1999;189:683 692

156. Hunter MG, Avalos BR. Deletion of a critical internalization domain in the G-CSFR in acute my elogenous leukemia preceded by severe congenital neutropenia. Blood. 1999;93:440-446.

157. Rauprich P, Kasper B, Tidow N, Welte K. The protein tyrosine kinase JAK2 is activated in neutrophils from patients with severe congenital neutropenia. Blood. 1995;86:4500-4505.

158. Ward AC, van Aesch YM, Gits J, et al. Novel point mutation in the extracellular domain of the granulocyte colony-stimulating factor (G-CSF) receptor in a case of severe congenital neutropenia hyporesponsive to G-CSF treatment. J Exp Med. 1999:190:497-507.

159. Youssoufian H, Longmore G, Neumann D, Yoshimura A, Lodish HF. Structure, function and activation of the Epo receptor. Blood. 1993;81: 2223-2236.

160. Arcasoy MO, Harris KW, Forget BG. A human erythropoietin receptor gene mutant causing familial erythrocytosis is associated with deregula- tion of the rates of Jak2 and Stat5 inactivation. Exp Hematol. 1999;27:63-74.

161. De la Chapelle A, Träskelin AL, Juvonen E. Truncated erythropoietin receptor causes dominantly inherited benign human erythrocytosis. Proc Natl Acad Sci U S A. 1993;90:4495-4499.

162. Sokol L, Luhovy M, Guan Y, Prchal JF, Semenza GL, Prchal IT. Primary familial polycythemia: a frameshift mutation in the erythropoietin receptor gene and increased sensitivity of erythroid progenitors to erythropoietin. Blood. 1995;86:15-22.

163. Fanconi G. Familial constitutional panmyelocytopathy, Fanconi's anemia (F.A.), I: clinical aspects. Semin Hematol. 1967;4:233-240.

164. Billardon B, Moustacchi E. Comparison of the sensitivity of Fanconi's anemia and normal fibroblasts of sister-chromatic exchanges by photoaddition of mono- and bi-functional psoralens. Mutat Res. 1986;174:241-246.

165. Whitney MA, Royle G, Low MJ, et al. Germ cell defects and hematopoietic hypersensitivity to $\gamma$-interferon in mice with a targeted disruption of the Fanconi anemia C gene. Blood. 1996;88:4958.

166. Rathbun RK, Faulkner GR, Ostroki MH, et al. Inactivation of the Fanconi anemia group $\mathrm{C}$ gene augments interferon-gamma-induced apoptotic responses in hematopoietic cells. Blood. 1997; 90:974-985.

167. Pang Q, Fagerlie S, Christianson TA, Keeble W, Bagby GC. The Fanconi anemia (FA) protein FAC is required for recruitment of Stat1 to the IFN $\gamma$ receptor complex [abstract]. Blood. 1998;92:476a.

168. Gutterman JU. Cytokine therapeutics: lessons from interferon $\alpha$. Proc Natl Acad Sci U S A. 1994; 91:1198-1205.

169. Kuzel TM, Roenigk HH, Samuelson E, et al. Effectiveness of interferon alpha-2a combined with phototherapy for mycosis fungoides and the Sezary syndrome. J Clin Oncol. 1995;13:257-263.

170. Sun WH, Pebon C, Alsayed Y, et al. Interferon- $\alpha$ resistance in a cutaneous T-cell lymphoma cell line is associated with lack of STAT1 expression. Blood. 1998;91:570-576.

171. Wong LH, Krauer KG, Hatzinisiriou I, et al. Interferon-resistant human melanoma cells are deficient in ISGF3 components, STAT1, STAT2, and p48-ISGF3 $\gamma$. J Biol Chem. 1996;272:28,77928,785 .

172. Sakamoto $H$, Yasukawa $H$, Masuhara $M$, et al. A Janus kinase inhibitor, JAB, is an interferon- $\gamma$ inducible gene and confers resistance to interferons. Blood. 1998;92:1668-1676.

173. Hoefsloot LH, van Amelsvoort MP, Broeders LC et al. Erythropoietin-induced activation of STAT5 is impaired in the myelodysplastic syndrome. Blood. 1997;89:1690-1700.

174. Tabrizi M, Yang W, Jiao H, et al. Reduced Tyk2/ SHP-1 interaction and lack of SHP-1 mutation in a kindred of familial hemophagocytic lymphohis tiocytosis. Leukemia. 1998;12:200-206.

175. Taylor N, Uribe L, Smith S, Jahn T, Kohn DB, Weinberg K. Correction of interleukin-2 receptor function in X-SCID lymphoblastoid cells by retrovirally mediated transfer of the gamma-c gene. Blood. 1996;87:3103-3107.

176. Bunting KD, Sangster MY, Ihle JN, Sorrentino BP. Restoration of lymphocyte function in Janus kinase 3-deficient mice by retroviral-mediated gene transfer. Nat Med. 1998;4:58-64.

177. Chen X, Vinkemeier U, Zhao Y, Jeruzalmi D, Darnell JE Jr, Kuriyan J. Crystal structure of a tyrosine phosphorylated STAT-1 dimer bound to DNA. Cell. 1998;93:827-839.

178. Becker S, Groner B, Muller CW. Three-dimensional structure of the Stat3 beta homodime bound to DNA. Nature. 1998;394:145-151.

179. Kaplan MH, Schindler U, Smiley ST, Grusby MJ. Stat6 is required for mediating responses to IL-4 
and for the development of Th2 cells. Immunity. 1996;4:313-319.

180. Kaplan MH, Wurster AL, Grusby MJ. A signal transducer and activator of transcription (Stat)4 independent pathway for the development of $T$ helper type 1 cells. J Exp Med. 1998;188:1191-1196.

181. Mui AL-F, Wakao H, Kinoshita T, Kitamura T, Miyajima A. Suppression of interleukin-3-induced gene expression by a C-terminal truncated Stat5: role of Stat5 in proliferation. EMBO J. 1996;15: 2425-2433.

182. Matsumura I, Ishikawa J, Nakajima K, et al. Thrombopoietin-induced differentiation of a human megakaryoblastic leukemia cell line, CMK, involves transcriptional activation of p21(WAF1/ Cip1) by STAT5. Mol Cell Biol. 1997;17:29332943.

183. Matsumura I, Kitamura T, Wakao H, et al. Transcriptional regulation of the cyclin D1 promoter by STAT5: its involvement in cytokine-dependent growth of hematopoietic cells. EMBO J. 1999;18: 1367-1377.

184. Shuai K, Halpern J, ten Hoeve J, Rao X, Sawyers CL. Constitutive activation of STAT5 by the BCR$\mathrm{ABL}$ oncogene in chronic myelogenous leukemia. Oncogene. 1996;13:247-254.

85. Chai SK, Nichols GL, Rothman P. Constitutive activation of JAKs and STATs in BCR-Abl-expressing cell lines and peripheral blood cells de rived from leukemic patients. J Immunol. 1997; 159:4720-4728.

186. Carlesso N, Frank DA, Griffin JD: Tyrosyl phos- phorylation and DNA binding activity of signal transducers and activators of transcription (STAT) proteins in hematopoietic cell lines transformed by Bcr/Abl. J Exp Med. 1996;183:811-820.

187. Frank DA, Varticovski L. BCR/abl leads to the constitutive activation of Stat proteins, and shares an epitope with tyrosine phosphorylated Stats. Leukemia. 1996;10:1724-1730.

188. Danial NN, Pernis A, Rothman PB. Jak-STAT signalling induced by the $v$-abl oncogene. Science. 1995;269:1875-1877.

189. Yu C-L, Jove R, Burakoff SJ. Constitutive activation of the Jak kinase-STAT pathway in T lymphoma overexpressing the lck protein tyrosine kinase. J Immunol. 1997;159:5206-5210.

190. Zhang Q, Nowak I, Vonderheid EC, et al. Activation of Jak/STAT proteins involved in signal transduction pathway mediated by receptor for interleukin 2 in malignant T lymphocytes derived from cutaneous anaplastic large T-cell lymphoma and Sezary syndrome. Proc Natl Acad Sci U S A. 1996;93:9148-9153.

191. Nielsen M, Kaktoft K, Nordahl M, et al. Constitutive activation of a slowly migrating isoform of STAT3 in mycosis fungoides: tyrphostin AG490 inhibits STAT3 activation and growth of mycosis fungoides tumor cell lines. Proc Natl Acad Sci U S A. 1997;94:6764-6769.

192. Lund TC, Garcia R, Medveczky MM, Jove R, Medveczky PG. Activation of STAT transcription factors by herpesvirus Saimiri Tip-484 requires p56lck. J Virol. 1997;71:6677-6682.

193. Weber-Nordt RM, Egen C, Wehinger J, et al. Constitutive activation of STAT proteins in primary lymphoid and myeloid leukemia cells and in Epstein-Barr virus (EBV)-related lymphoma cell lines. Blood. 1996;88:809-816.

194. Gouilleux-Gruart B, Gouilleux F, Desaint C, et al STAT-related transcription factors are constitutively activated in peripheral blood cells from acute leukemia patients. Blood. 1996;87:1692-1697.

195. Hayakawa F, Towatari M, lida H, et al. Differential constitutive activation between STAT-related proteins and MAP kinase in primary acute myelogenous leukaemia. Br J Haematol. 1998;101:521-528.

196. Xia Z, Baer MR, Block AW, Baumann H, Wetzler M. Expression of signal transducers and activators of transcription proteins in acute myeloid leukemia blasts. Cancer Res. 1998;58:3173-3180.

197. Liu R, Fan C, Garcia R, Jove R, Zuckerman KS. Constitutive activation of the JAK/STAT5 signal transduction pathway correlates with growth factor independence of megakaryocytic leukemic cell lines. Blood. 1999;93:2369-2379.

198. Migone T-S, Lin J-X, Cereseto A, et al. Constitutively activated Jak-STAT pathway in T cells transformed with HTLV-I. Science. 1995;269:79-81.

199. Takemoto S, Mulloy JC, Cereseto A, et al. Proliferation of adult T cell leukemia/lymphoma cells is associated with the constitutive activation of JAK/ STAT proteins. Proc Natl Acad Sci U S A. 1997; 94:13,897-13,902. 